(C) 2014

Богач М. В., доктор ветеринарних наук

Одеська дослідна станція ННЦ «ЕКВМ»

Шайдюк I. В., аспірант

(науковий керівник - доктор ветеринарних наук М. В. Богач)

Одеський державний аграрний університет

\title{
ЗАСТОСУВАННЯ ВЕРМАЛЮ ЗА ГАНГУЛЕТЕРАКОЗУ КАЧОК І ЙОГО ВПЛИВ НА БІОХІМІЧНІ ПОКАЗНИКИ СИРОВАТКИ КРОВІ
}

\section{Рецензент - доктор ветеринарних наук В. О. Свстаф'єва}

У статті за експериментальної гангулетеракозної інвазії качок визначено ефективність протипаразитарного засобу «Вермаль» (ННЦ «ІЕКВМ»), щчо склала 90,9\%, а інтенсефективність - 95,6\%. Застосований «Вермаль» спричинив імуносупресивну дію впродовж 3-10 діб після застосування, а починаючи з 10-ї доби, препарат нормалізував вміст загального білку та глобулінових фракиій, призвів до зниження рівня

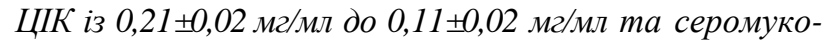

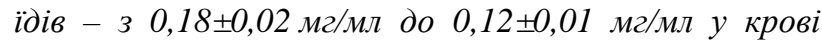
качок.

Ключові слова: гангулетеракоз, ефективність, інтенсефективність, кров, біохімія, качки.

Постановка проблеми. Гангулетеракоз качок та гусей - широко розповсюджене захворювання, що викликається паразитуванням у сліпих (рідко - в товстих) кишках нематоди Ganguleterakis dispar (Schrank, 1790). Гангулетеракоз негативно впливає на ріст і розвиток молодняку, несучість дорослої птиці за рахунок порушення всмоктувальних процесів у кишечнику і розвитку дефіцитів поживних речовин, мінералів та вітамінів [6].

На промислових підприємствах, де порушується санітарний режим, інвазується значна частина поголів'я птиці. Зараженість качок батьківського і ремонтного поголів'я досягає близько $30 \%[2,9]$. У присадибних господарствах півдня України екстенсивність інвазії становить 37,6\% за середньої інтенсивності від 18,5 до 22,1 екз./птицю [3].

Аналіз останніх досліджень і публікацій, у яких започатковано розв'язання проблеми. Механізму впливу антгельмінтиків на фізіологічні процеси в організмі хазяїна присвячені роботи багатьох дослідників. Відомо, що паразитичні організми спричинюють загальний розлад обмінних процесів і нейрогуморальної регуляції організму, що проявляється алергією різного характеру та імунодепресією [5].

Літературні дані свідчать про широке використання і високу ефективність альбену, бровада- золу, брованолу та левамізолу за нематодозу качок та гусей $[1,8]$. Існують повідомлення як вітчизняних, так і закордонних авторів про імунодепресивні властивості більшості антгельмінтиків $[4,7]$.

Мета і завдання досліджень. Метою роботи було за експериментальної гангулетеракозної інвазії качок провести оцінку ефективності протипаразитарного засобу «Вермаль» (розробка ННЦ «ІЕКВМ») та його впливу на біохімічні показники сироватки крові.

У завдання досліджень входило визначити інтенс- та екстенсефективність антгельмінтика.

Матеріали і методи. Гангулетеракозну інвазію було відтворено експериментальним шляхом на 11 качках 90-добового віку кросу «Благоварський» шляхом інвазування 7-добовою інвазійною культурою яєць Ganguleterakis dispar, яку задавали індивідуально після 12-годинної голодної дієти у дозі 200土20 екз./птицю.

Качки дослідної та контрольної груп були розміщені в окремі клітки й знаходились в однакових умовах і на однаковому раціоні.

Починаючи з 30-ї доби, після проведеного зараження, у фекаліях усіх качок реєстрували яйця гангулетеракісів із середньою інтенсивністю від

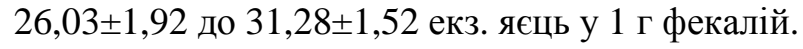

Згідно зі схемою досліду, качкам дослідної групи $(\mathrm{n}=11)$ задавали вермаль із розрахунку 10 мг/кг маси тіла впродовж двох діб вільно груповим методом, проводячи змішування антигельмінтика 3 третиною корму, а після остаточного його поїдання давали решту корму згідно з раціоном. Птиця контрольної групи отримувала корм без антгельмінтиків (згідно з раціоном).

Під час застосування протипаразитарного засобу у ході проведення досліду побічних явищ у качок не виявлено.

3 метою визначення впливу «Вермалю» на показники загальної резистентності організму качок за гангулетеракозної інвазії відбиралися зразки крові до хіміопрофілактики та на 3-ю, 10-у й 


\section{ВЕТЕРИНАРНА МЕДИЦИНА}

21-у добу після лікування. Кров у кількості 1 мл відбирали за загальноприйнятою методикою 3 vena axilaris.

Визначали такі показники:

- рівень загального білку та його фракції (за біуретовою реакцією й турбідіметричним методом відповідно);

- циркулюючі імунні комплекси (за Гриневичем і Алферовим, 1981);

- серомукоїди (по Weimer. A, Moshin, 1952).

Результати досліджень. Визначення екстенсефективності препарату за гангулетеракозної інвазії проводили за даними копроовоскопічних досліджень, починаючи $з$ третьої доби та на 10-у i 21-у доби після його застосування (табл. 1).

Встановлено, що застосування вермалю сприяло зниженню екстенсивності інвазії. Так, на 3-ю добу після обробки препаратом $\mathrm{EI}=36,37 \%$, тобто від інвазії звільнилося 7 качок, на 10-у добу повністю від інвазії звільнилося 9 качок і показник ЕІ склав 27,27 \%, а на 21-у добу досліду ли- ше одна качка залишилась інвазованою, показник ЕЕ склав 90,91\%.

У контролі екстенсивність інвазії як до обробки, так і впродовж 3-ї, 10-ї і 21-ї доби залишалася на рівні $100 \%$.

Також визначено інтенсефективність «Вермалю» за гангулетеракозної інвазії качок (табл. 2).

Після застосування вермалю качкам дослідної групи вже на третю добу досліду інтенсивність

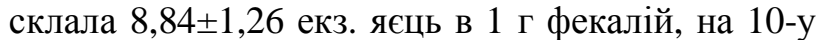
добу - 5,16士0,42 екз. яєць і на 21-у добу досліду вона залишилася мінімальною - 1,16 $\pm 0,56$ екз. яєць в 1 г фекалій, а сам показник інтенсефективності по цій групі склав 95,6 \%.

На відміну від дослідної групи птиці, у контролі впродовж усього терміну досліду інтенсивність інвазії знаходилась майже на однаковому

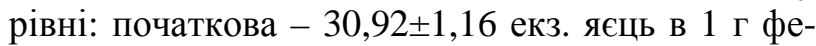
калій, на 3-ю добу - 27,11 екз. яєць, на 10-у добу 32,12 екз. яєць та на $21-\mathrm{y}-32,24 \pm 1,27$ екз. яєць в 1 г фекалій.

\section{1. Екстенсефективність вермалю за гангулетеракозної інвазії качок $(M \pm m, n=11)$}

\begin{tabular}{|c|c|c|c|c|c|}
\hline \multirow{2}{*}{$\begin{array}{c}\text { Групи птиці } \\
\text { (препарати) }\end{array}$} & \multicolumn{4}{|c|}{ ЕІ, \% } & \multirow{2}{*}{ ЕЕ, \% } \\
\cline { 2 - 5 } & \multirow{2}{*}{ до обробки } & \multicolumn{3}{|c|}{ після обробки, доба } & \\
\cline { 3 - 5 } & & $3-я$ & $10-\mathrm{a}$ & $21-\mathrm{a}$ & \\
\hline Дослідна & 100 & 36,37 & 27,27 & 9,09 & 90,91 \\
\hline Контрольна & 100 & 100 & 100 & 100 & - \\
\hline
\end{tabular}

\section{2. Інтенсефективність вермалю за гангулетеракозної інвазї̈ качок, $(M \pm m, n=11)$}

\begin{tabular}{|c|c|c|c|c|c|}
\hline \multirow{2}{*}{$\begin{array}{c}\text { Групи птиці } \\
\text { (препарати) }\end{array}$} & \multicolumn{4}{|c|}{ II, екз. яєць в 1 г фекалій } & \multirow{2}{*}{ IE, \% } \\
\cline { 2 - 5 } & \multirow{2}{*}{ до обробки } & \multicolumn{3}{|c|}{ після обробки, доба } & \\
\cline { 3 - 5 } & & $3-я$ & $10-\mathrm{a}$ & $21-\mathrm{a}$ & \\
\hline Дослідна & $26,53 \pm 1,22$ & $8,84 \pm 1,26$ & $5,16 \pm 0,42$ & $1,16 \pm 0,56$ & 95,6 \\
\hline Контрольна & $30,92 \pm 1,16$ & $27,11 \pm 1,76$ & $32,12 \pm 1,14$ & $32,24 \pm 1,27$ & - \\
\hline
\end{tabular}

\section{3. Біохімічні показники сироватки крові качок за експериментальної гангулетеракозної інвазії}

за дегельмінтизації вермалем $(M \pm m, n=11)$

\begin{tabular}{|c|c|c|c|c|c|}
\hline \multirow{2}{*}{ Показник } & \multicolumn{5}{|c|}{ Період досліджень, діб } \\
\cline { 2 - 6 } & до застосув. & 3 -я & 10 -а & $15-\mathrm{a}$ & 21 -а \\
\hline Загальний білок, г/л & $53,61 \pm 1,25$ & $53,87 \pm 0,92$ & $53,88 \pm 0,59$ & $54,03 \pm 0,25$ & $54,67 \pm 1,02^{*}$ \\
\hline Альбуміни, г/л & $22,26 \pm 0,57$ & $21,12 \pm 1,23$ & $22,75 \pm 1,02$ & $25,65 \pm 0,49$ & $27,82 \pm 0,72^{*}$ \\
\hline Глобуліни, г/л & $31,35 \pm 0,69$ & $32,75 \pm 1,12$ & $31,13 \pm 0,52$ & $28,38 \pm 0,75$ & $26,85 \pm 1,08^{*}$ \\
\hline$\alpha$-глобуліни, г/л & $11,02 \pm 0,53$ & $11,25 \pm 1,72$ & $10,95 \pm 0,26$ & $10,26 \pm 0,14$ & $10,02 \pm 0,23^{*}$ \\
\hline$\beta$-глобуліни, г/л & $9,12 \pm 1,16$ & $9,26 \pm 0,11$ & $9,16 \pm 0,32$ & $8,69 \pm 0,65$ & $7,92 \pm 0,14^{*}$ \\
\hline$\gamma$-глобуліни, г/л & $11,21 \pm 0,36$ & $12,24 \pm 0,27$ & $11,02 \pm 0,25$ & $9,43 \pm 1,08$ & $8,91 \pm 0,26^{*}$ \\
\hline Коефіцієнт А/Г & 0,7 & 0,6 & 0,7 & 0,9 & 1,0 \\
\hline АлАТ, ммоль/л & $0,59 \pm 0,01$ & $0,62 \pm 0,02$ & $0,52 \pm 0,01$ & $0,46 \pm 0,02$ & $0,32 \pm 0,01^{*}$ \\
\hline АсАТ, ммоль/л & $0,86 \pm 0,02$ & $0,92 \pm 0,01$ & $0,62 \pm 0,02$ & $0,57 \pm 0,04$ & $0,52 \pm 0,01^{*}$ \\
\hline ЦІК, мг/мл & $0,19 \pm 0,01$ & $0,21 \pm 0,02$ & $0,18 \pm 0,03$ & $0,17 \pm 0,02$ & $0,11 \pm 0,02^{*}$ \\
\hline Серомукоїди, мг/мл & $0,18 \pm 0,02$ & $0,19 \pm 0,01$ & $0,17 \pm 0,02$ & $0,15 \pm 0,01$ & $0,12 \pm 0,01^{*}$ \\
\hline
\end{tabular}

Примітка: * - зміна показника суттєва порівняно з контролем $(\mathrm{P}<0,05)$ 
Результати біохімічних досліджень сироватки крові інвазованих качок до застосування «Вармалю» та на 3-ю, 10-у, 15-у і 21-у доби наведено в таблиці 3.

За період досліджень зареєстровано підвищення кількості загального білку вже на 15-у та 21-у доби досліду до $54,67 \pm 1,02$ г/л $(\mathrm{P}<0,05)$ проти $53,61 \pm 1,25$ г/л. Водночас відбулися суттєві зміни щодо вмісту альбумінів: на 3-ю добу досліду знизилась їх кількість із 22,26 $\pm 0,57$ до 21,12 $\pm 1,23$ г/л. Майже на такому рівні вміст альбумінів залишився і на 10-у добу досліду - 22,75 1,02 г/л і лише на 15-у добу зріс до $25,65 \pm 0,49$ г/л, а на 21-у добу $27,82 \pm 0,72$ г/л $(\mathrm{P}<0,05)$. У період спостережень вміст $\alpha$-глобулінів незначно коливався - від $11,02 \pm 0,53$ г/л до $11,25 \pm 1,72$ г/л на третю добу й на 21-у добу становив $10,02 \pm 0,23$ г/л $(\mathrm{P}<0,05)$. Слід зазначити, що фракція $\beta$-глобулінів упродовж досліду поступово зменшувалася 3 $9,12 \pm 1,16$ г/л до $9,16 \pm 0,32$ г/л на 10-у добу, $8,69 \pm 0,65$ г/л на $15-$ д добу і найнижчою була на 21 -у добу - 7,92 $\pm 0,44$ г/л $(\mathrm{P}<0,05)$. Якщо за гангулетеракозу качок фракція $\gamma$-глобулінів стано-

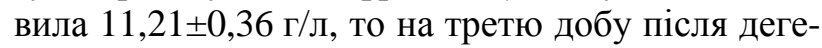
льмінтизації вермалем вона зросла до $12,24 \pm 0,27$ г/л, на 10-у добу була на рівні $11,02 \pm 0,25$ г/л і лише на 15 -у добу знизилася до $9,43 \pm 1,06$ г/л. До меж норми $\gamma$-глобуліни наблизилися лише на 21-у добу досліду, вміст яких

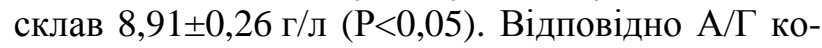
ефіцієнт у інвазованих качок на початку досліду

\section{БІБЛІОГРАФІЯ}

1. Березовский А. В., Поживил А. И., Шевченко А. Н. Современные лекарственные средства фармакокорекции и химиопрофилактики животных. - К. : Ветинформ, 2007. - 240 с.

2. Богач М. В., Бездєтко Л. С. Кишкові інвазії водоплавної птиці в господарствах різних форм власності Одеської області // Аграрний вісник Причорномор'я : зб. наук. праць. - Одеса, 2008. Вип. 42. - С. 126-129.

3. Богач М. В., Харишина Т. В., Шайдюк I. В. Сезонна та вікова динаміка гангулетеракозу водоплавної птиці в господарствах Одеської області // Наук.-теорет. зб. Житомирського національного агроекологічного університету. - «Інвазійні хвороби тварин». - Житомир, 2012. - Вип. 1 (32). - T. 3. - Ч. 1. - C. 22-25.

4. Герасимчик В. А., Берсенева Л. И. Ассоциативные эндопаразитозы гусей в фермерских хозяйствах и меры борьбы с ними // Зб. наук. праць Луганського національного аграрного університету. - Луганськ, 2003. - №31/43. - С. 135-138. становив 0,7 , на третю добу знизився до 0,6 , на 10 -у добу став 0,7 і лише з 15 -ої доби зріс до 0,9 , а на 21-у добу був 1,0 . Показники активності АлАТ та АсAТ, які у хворої птиці становили $0,59 \pm 0,01$ ммоль/л та 0,86 $\pm 0,02$ ммоль/л відповідно, дещо зросли на третю добу - до 0,62 $\pm 0,02$ ммоль/л та 0,92 $\pm 0,01$ ммоль/л. На $15-$ д добу досліду зареєстровано зниження показників активності АлАТ до рівня $0,46 \pm 0,02$ ммоль/л та АсАТ до $0,57 \pm 0,04$ ммоль/л $(\mathrm{P}<0,05)$. У інвазованої птиці на початку досліду рівень ЦІК становив $0,19 \pm 0,01$ мг/мл, який суттєво зріс до $0,21 \pm 0,02$ мг/мл на третю добу і на досить високому рівні $0,17 \pm 0,02$ мг/мл - утримувався до $15-і$ доби досліду, а вже на 21-у добу він становив $0,11 \pm 0,02$ мг/мл $(\mathrm{P}<0,05)$. Також до початку досліду була

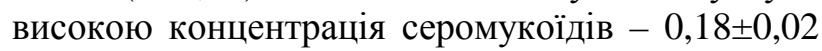
мг/мл, а після застосування вермалю на третю добу становила $0,19 \pm 0,01$ мг/мл, на 10 -у добу почала зменшуватися до $0,17 \pm 0,02$ мг/мл і вже на 21-у добу становила $0,12 \pm 0,01$ мг/мл.

\section{Висновки:}

1. За експериментальної гангулетеракозної інвазії качок екстенсефективність вермалю становила 90,9\%, а інтенсефективність - 95,6\%.

2. Застосований «Вермаль» спричинив імуносупресію впродовж 3-10-ї доби після застосування. Доведено, що починаючи з 10-ї доби препарат нормалізував вміст загального білку і глобулінових фракції, сприяв зниженню рівня ЦІК та серомукоїдів у крові качок.

5. Даугалиева Э. Х., Курочкина К. Г., Аринкин А. В. Особенности иммунитета при гельминтозах // Ветеринария. - 1996. - №7. - С. 37-38.

6. Иринчук B. В. Эпизоотология гангулетеракидоза уток в Одесской области // Болезни птиц при интенсивных методах ведения отрасли: межвуз. сб. науч. тр. - Х., 1988. - С. 70-75.

7. Косенко М., Кочюмбас І., Косенко Ю. [та ін.] Контроль впливу ветеринарних лікарських засобів на стан імунітету тварин // Ветеринарна медицина України. - 2004. - №1. - С. 43-44.

8. Михайлютенко С.М. Кишкові нематодози гусей (поширення, діагностика та заходи боротьби): автореф. дис. ... канд. вет. наук: 16.00.11. - Київ, 2014. - 20 с.

9. Хазиев Г. З., Сагитова А. С. Зависимость степени зараженности и видового состава гельминтов гусей от технологии ведения гусеводства // Материалы докладов науч. конф. «Теория и практика борьбы с паразитарными болезнями». M., 1990. - C. 284-287. 